九州大学学術情報リポジトリ

Kyushu University Institutional Repository

\title{
A New Sex-Linked Mutation in The Silkworm Bombyx Mori L
}

Tanaka, Yoshimaro

Sericultursl Laborntory, Kyushu Imperial University

https://doi.org/10.5109/22325

出版情報：九州大学大学院農学研究院紀要. 1 (2)，pp.135-150，1924-03. Kyushu Imperial University バージョン：

権利関係 : 


\title{
A NEW SEX-LINKED MUTATION IN THE SILKWORM, BOMBYX MORI L'.
}

\author{
Yoshimaro TANAKA
}

As I have described in my previous papers (1917, 1922) there had been found a case of sex-linkage in the silkworm with regard to inheritance of the translucent skin character. In 19I8, on the other hand, 1 happened to find a number of abnormal larvae in a hybrid strain reared in my silkworm-house. In the subsequent years, the hereditary behaviour of this mutant character, the "elongate" as I called it, has been thoroughly studied, and now it has become evident that the mutation in question is linked to sex, and forms a second case of sexlinkage in the silkworm. 'Another interesting point in this connection is the occasional appearance of exceptional males in the course of the experiments. At first, I supposed it to be a similar case to the nondisjunction of BRIDGES (I9I6); the later experiments have, however, revealed that it was due to mere somatic variation, but not due to any genetic irregularities.

\section{CHARACTERISTICS OF THE " ELONGATE"}

Larva (Plate I, Fig. I). First and second abdominal segments are rendered markedly long, and the skin is longitudinally stretched, resulting in the disappearance of the intersegmental folds in this region. That the body is much softer to the touch than in the normal larva is another characteristic of the mutant.

Pupa (Plate I, Figs. 2 and 3). The Characteristic of the mutation is most conspicuously developed in the pupal stage. The brown coloured primary cuticula is torn in the boundaries of the first and second, second and third, and often also of the third and fourth abdominal segments, disclosing the colourless secondary or inner cuticula as two or three narrow white bands in those parts. The second segment, which is normally the smallest of the pupal abdominal segments, is rendered more or less larger, sometimes bigger than any of other abdominal

I Contributions from the Sericultural Laboratory, Kyushu Imperial University, No. r. 
segments. In such extreme cases as shown in Fig. 2, to the right, and in Fig. 3, the middle of the lower row, the segment in question attained a tremendous size, making the animal look like a humpback.

Moth. The first abdominal segment is longer than in the normal.

Cocoon. The cocoons spun by the elongate larvae are often disformed and are less hard and firm than those spun by the normals.

The mentioned characteristics of the mutant are, as a rule, distinct and easily distinguishable from the normal type.

\section{ORIGIN OF THE “ELONGATE”}

-In a hybrid family, No. $18 a m 6$, reared in the spring of 1918 , a number of abnormal larvae attracted my attention, in which the anterior segments were markedly long in comparison with the posterior ones. When picked up with the fingers, they contracted the posterior body, but not the anterior, while the normals contracted the whole body, thus making the peculiarity even more striking. When killed, the peculiarity usually became less marked. Such abnormal caterpillars, later called "elongates," were separated and counted. The result follows:

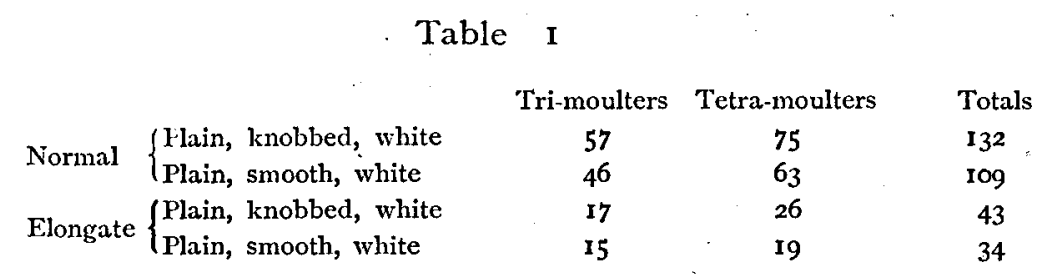

That is 241 normals to 77 elongates, 318 in all. The sexes were not discriminated in the larval stage, but there is a strong reason for the supposition that the 77 abnormals were all female, because all elongate individuals, $2 \mathrm{I}$ in number, allowed to develop into moths were female.

The pedigree of this family is given below. 


\section{Table 2}

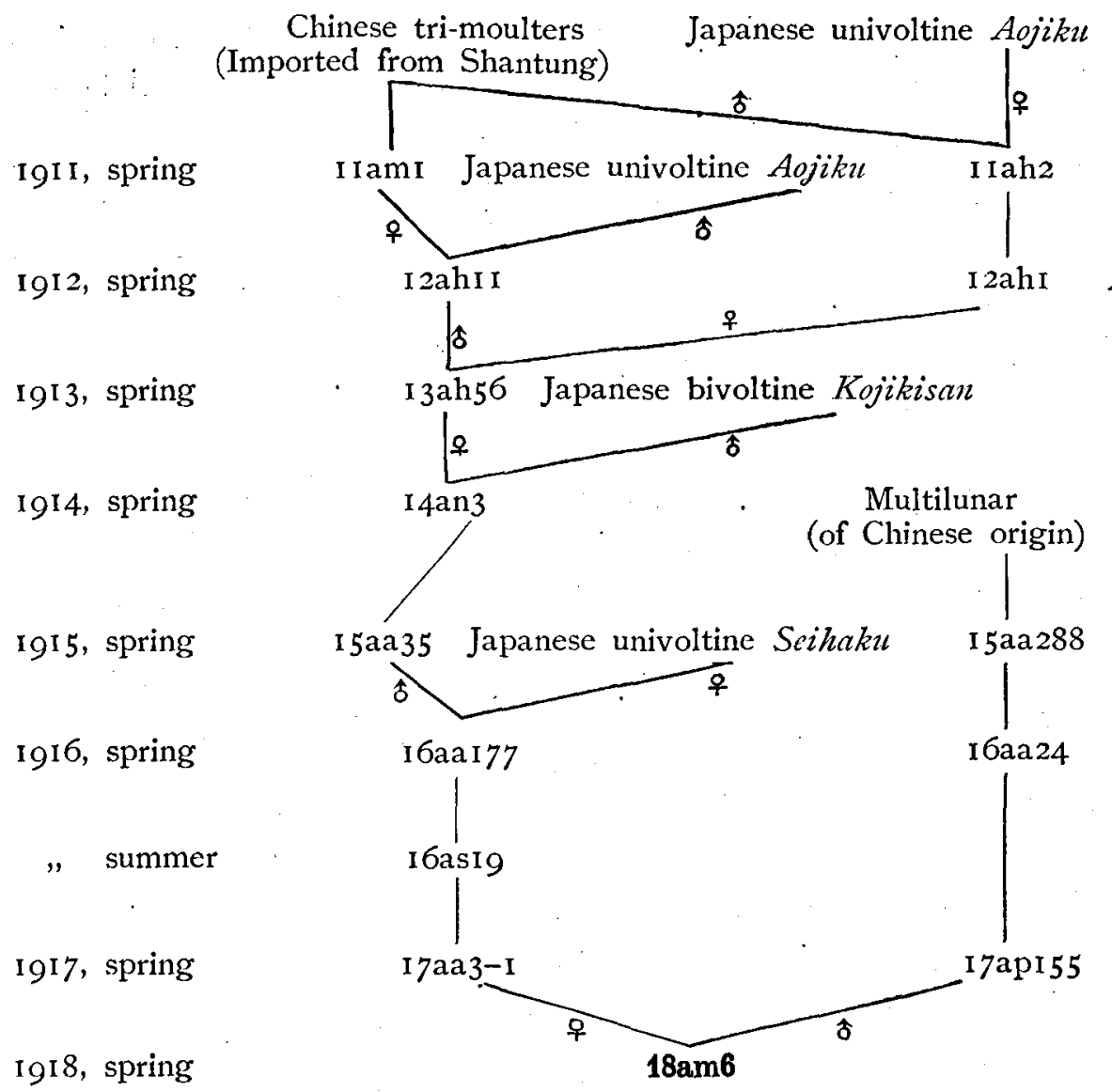

The female parent of the family $I 8 a m 6$ was plain, smooth, white blooded, while the male parent was plain, knobbed, white-blooded.

As is evident in the pedigree, the female parent originates from a Chinese tri-moulting race to which Japanese races (Aojiku, Kojikisai and Seihaku) were crossed in three different generations, while the male parent is a pure breed of Chinese origin. All these strains had been cultured under my own observation for several (at least four) generations, and in no case had so many abnormals (elongates) been found up to the date mentioned. 


\section{EXPERIMENTAL RESULTS}

Since the elongate individuals were obtained, for the first time, in I9I8, they and their offspring formed the sole source of the elongates in the following experiments. Their normal mates were taken from various strains reared in my silkworm-house for many generations and proved to be pure normal so far as the character in question is concerned, e.g. Chiyozuru, Shirogasuri, Arayahime, stony, black pupa, monsterproducing, translucent etc., thus resulting in the segregation of markings, translucency, number of moults, pupal and cocoon colours, and some other characters. For the sake of simplicity, however, I will mention the segregation of the elongate versus the normal and the sexes only, disregarding all other characters for the present.

\section{A. Elongate 우 $\times$ Normal 송}

a) $F_{1}$

Family No.
Igam6-I
rgani6-2
I9am6-3
$20 \mathrm{bm} 6-3$
$22 \mathrm{am} 6-9$
$22 \mathrm{am} 6-10$
$22 \mathrm{am} 6-11$
$22 \mathrm{~cm} 6-2$
$22 \mathrm{~cm} 6-3$
$22 \mathrm{~cm} 6-4$
$22 \mathrm{~cm} 6-23$
$22 \mathrm{~cm} 6-26$
Totals
Expected

Table 3

\begin{tabular}{|c|c|c|}
\hline Normals & Elongates & Totals \\
\hline 398 & o & 398 \\
\hline 340 & o & 340 \\
\hline 322 & o & 322 \\
\hline 372 & $\circ$ & 372 \\
\hline $267\left\{\begin{array}{l}\text { 오133 } \\
\text { 今134 }\end{array}\right.$ & 0. & 267 \\
\hline 349 & Io (all $\widehat{0} \delta$ ) & 359 \\
\hline 247 & I (今) & 248 \\
\hline $122\left\{\begin{array}{l}\text { 우55 } \\
\text { 今67 }\end{array}\right.$ & 0 & 122 \\
\hline 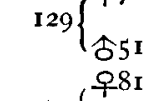 & 2 (今今) & I3I \\
\hline I79 $\left\{\begin{array}{l}T 98 \\
\text { 今人 }\end{array}\right.$ & o & 179 \\
\hline I24 $\begin{array}{r}\text { 今84 } \\
\text { 우56 }\end{array}$ & I (今) & $\mathbf{1 2 5}$ \\
\hline $106\left\{\begin{array}{l}150 \\
\text { 今50 }\end{array}\right.$ & o & 106 \\
\hline $97\left\{\begin{array}{c}5_{52} \\
\end{array}\right.$ & 0 & 97 \\
\hline $\begin{array}{l}3052 \\
3066\end{array}$ & $\begin{array}{r}\text { I4 } \\
\text { o }\end{array}$ & 3066 \\
\hline
\end{tabular}


Summing up the families in which the sexes were distinguished, the result follows :

\begin{tabular}{|c|c|c|c|c|c|}
\hline \multirow[b]{2}{*}{ Experimental } & \multicolumn{2}{|c|}{ Normals } & \multicolumn{2}{|c|}{ Elongates } & Totals \\
\hline & $\frac{1}{488}$ & 㑒 & 우 & 今ิ & 1038 \\
\hline Theoretical & 519 & 519 & o & 0 & \\
\hline
\end{tabular}

b) $\mathrm{F}$

Table 4

\begin{tabular}{|c|c|c|c|}
\hline $\begin{array}{l}\text { Family No. } \\
\text { sgbm6-2 }\end{array}$ & $\begin{array}{l}\text { Normals } \\
232(ㅇ ㅗ+\$)\end{array}$ & $\begin{array}{l}\text { Elongates } \\
67 \text { (I7 moths emerged } \\
\text { were all 우우) }\end{array}$ & $\begin{array}{l}\text { 'Totals } \\
233\end{array}$ \\
\hline $19 \mathrm{bm} 6-3$ & 184 & 49 & 233 \\
\hline $19 \mathrm{bm} 6-4$ & 203 & $3 \mathbf{I}$ & 234 \\
\hline $20 \mathrm{~cm} 6-\mathrm{I}$ & I7I $\left\{\begin{array}{l}\text { 우 } 67 \\
\text { 今1 } 134 \\
\text { 오 } 86\end{array}\right.$ & $46\left\{\begin{array}{l}\text { 연 } \\
\text { 今 } 2 \\
\text { 의 }\end{array}\right.$ & 217 \\
\hline $20 \mathrm{~cm} 6-2$ & $278\left\{\begin{array}{l}7 \\
\text { 今 } 192\end{array}\right.$ & ${ }^{63} \begin{cases}703 \\
8 & 0 \\
880\end{cases}$ & $34 \mathrm{r}$ \\
\hline $2213 m 6-3$ & $222\left\{\begin{array}{l}\text { f } 75 \\
\text { 엉 } 47\end{array}\right.$ & $89\left\{\begin{array}{l}f 09 \\
\text { 占o } \\
\text { 우57 }\end{array}\right.$ & 3 II \\
\hline $22 \mathrm{bm} 6-4$ & 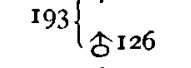 & 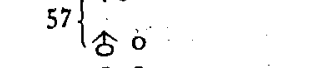 & 250 \\
\hline $2213 m 6-5$ & - $151\left\{\begin{array}{l}740 \\
\text { 今 } 111\end{array}\right.$ & ${ }^{8} 8\left\{\begin{array}{l}-73^{\circ} \\
\text { 号 } 0\end{array}\right.$ & 189 \\
\hline $22 \mathrm{hm} 6-6$ & $124\left\{\begin{array}{l}f \\
\text { f } 43 \\
\text { \& I }\end{array}\right.$ & $37\left\{\begin{array}{l}+ \text { } \\
\text { 今。 }\end{array}\right.$ & 161 \\
\hline $22 \mathrm{bm} 6-7$ & $113\left\{\begin{array}{l}\text { 委 } \\
\text { 古 } 80\end{array}\right.$ & $29\left\{\begin{array}{l}\text { 우29 } \\
\text { 占。 }\end{array}\right.$ & 142 \\
\hline $22 \mathrm{~cm} 6-2 \mathrm{I}-\mathrm{I}$ & I $33\left\{\begin{array}{l}\text { 우 } 49 \\
\text { 송 } 84\end{array}\right.$ & 30 $\left\{\begin{array}{l}\text { ㅇ3ㅇ } \\
\text { 今。 }\end{array}\right.$ & $16_{3}$ \\
\hline $22 \mathrm{~cm} 6-2 \mathrm{I}-2$ & $83\left\{\begin{array}{l}\text { 우 3I } \\
\text { 令 } 52\end{array}\right.$ & $29\left\{\begin{array}{l}\text { 우29 } \\
\text { 合。 }\end{array}\right.$ & II 2 \\
\hline $22 \mathrm{~cm} 6-2 \mathrm{I}-3$ & $206\left\{\begin{array}{l}\text { 우 71 } \\
\text { 1135 }\end{array}\right.$ & $61\left\{\begin{array}{l}\text { 우60 } \\
\text { t }\end{array}\right.$ & 267. \\
\hline $22 \mathrm{ch} 20$ & $70\left\{\begin{array}{l}\text { t } 22 \\
\text { 今 } 48\end{array}\right.$ & $2 x\left\{\begin{array}{l}\text { ț21 } \\
\hat{\delta} 0\end{array}\right.$ & 91. \\
\hline Totals & 2363 & 647 & 3010 \\
\hline Expected & $\begin{array}{l}2257.5 \\
+23.75\end{array}$ & 752.5 & \\
\hline Standard error & & \pm 23.75 & \\
\hline
\end{tabular}


Summing up the families in which sexes were discriminated, the result follows :

\begin{tabular}{|c|c|c|c|c|}
\hline & \multicolumn{2}{|c|}{$\begin{array}{c}\text { Normals } \\
1744\end{array}$} & \multicolumn{2}{|c|}{$\begin{array}{c}\text { Flongates } \\
500\end{array}$} \\
\hline & 우 & 令 & 우 & $\widehat{1}$ \\
\hline Fxperimental & 584 & 1160 & 497 & 3 \\
\hline Theoretical & $56 \mathrm{I}$ & II 22 & $5^{61}$ & 0 \\
\hline andard error & \pm 20.55 & \pm 23.69 & \pm 2 & \\
\hline
\end{tabular}

c) $\mathrm{F}_{3}$

I) $\mathrm{F}_{2}$ normals mated to each other gave the following result:

\section{Table 5}

Family No.
Igcm6-3
20am6-2
Totals

\begin{tabular}{ccc}
$\begin{array}{c}\text { Normals } \\
135\end{array}$ & Elongates & Totals \\
404 & 31 & 166 \\
\hline 539 & 120 & 524 \\
\hline 151 & 690
\end{tabular}

In these families, the sexes were not distinguished during the larval life. The elongate moths that emerged from No. 20ant-2, however, were all female, hence we can suppose that the same segregation as in $F_{2}$ occurred in both of the families:

2) The elongate females from $F_{2}$ generation were mated by their normal brothers, the result follows.

\section{Table 6}

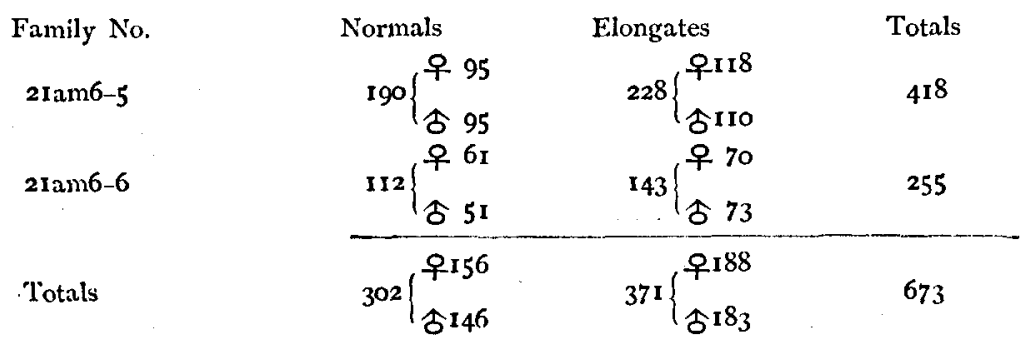


B. Normal 우 $\times$ Elongate 송

a) $\mathbf{F}_{1}$

\section{Table 7}

Family No.

22ain6-12

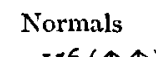

156 (合㑒)

22am6-13

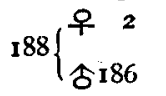

Elongates

Totals

$22 \mathrm{~cm} 6-5$

$22 \mathrm{~cm} 6-6$

$22 \mathrm{~cm} 6-7$

22cm6-22

$22 \operatorname{ch} 12-3$

I5I (all 令舍)

60 (all 古令)

137 (all 古令)

142 (all 우우)

298

21 (all 今े

167 (all 우우)

355

$75\left\{\begin{array}{l}\text { 우 I } \\ \text { 강 }\end{array}\right.$

140 (all 우오) 291

78 (all 우우) $\quad 138$

125 (all 우우) 262

28 (all 우우) 49

62 (all 우우) 137

Totals

Expected

Standard error

\begin{tabular}{|c|c|c|c|c|c|}
\hline & & 7 & & & \\
\hline 오 & 今 & 오 & 今 & i & I 530 \\
\hline 3 & 785 & 742 & 0 & & \\
\hline 0 & $\begin{array}{l}765 \\
+\end{array}$ & $\begin{array}{c}765 \\
+\end{array}$ & 0 & & \\
\hline
\end{tabular}

b) $\mathrm{F}_{2}$

Table 8

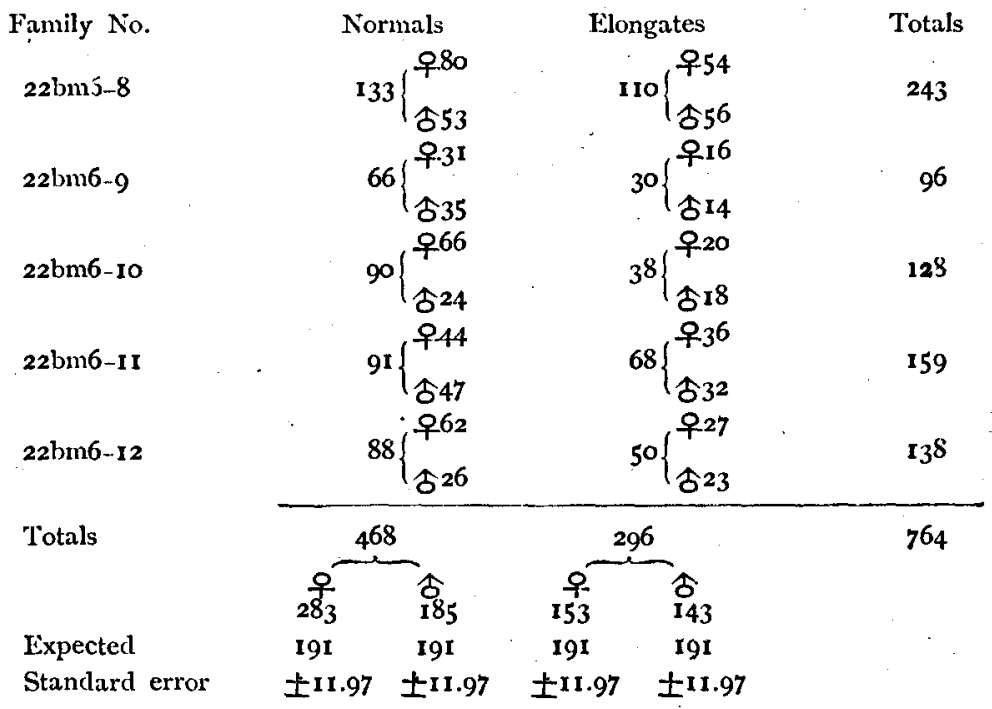


C. Back Crossing

a) Pure normal 우 $\times \mathrm{F}_{1}$ (normal 우 $\times$ elongate 1 ) normal 송

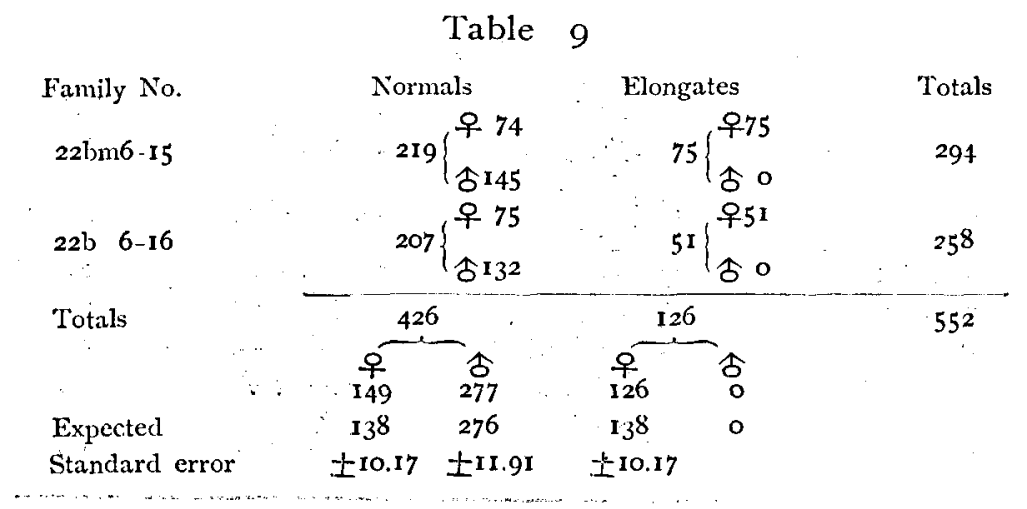

b) $F_{1}$ (normal 우 $\times$ elongate 1 ) elongate 우 $\times$ pure normal 송

Table Io

Family N̦o.

22bm6-2I

\begin{tabular}{|c|c|c|}
\hline Normals & Elongates & Totals \\
\hline $370\left\{\begin{array}{l}\text { 우195 } \\
\text { 이요 }\end{array}\right.$ & o & 370 \\
\hline
\end{tabular}

D. Pure Elongate Strains

In the summer of I92I, mating was made between elongate males and females, the offspring, that were reared in the spring of 1922 , consisted of the elongate only. There were eight families cultivated separately, in seven of which the number of individuals was counted as 2024. In regard to the two subsequent generations each generation was reared in two mixed lots, in which no exception was observed. In four families of these pure strains, sexes were discriminated before spinning, giving 568 females and 563 males, II3I altogether. The pedigree of the pure elongate strains is given below. 


\section{Table i I}

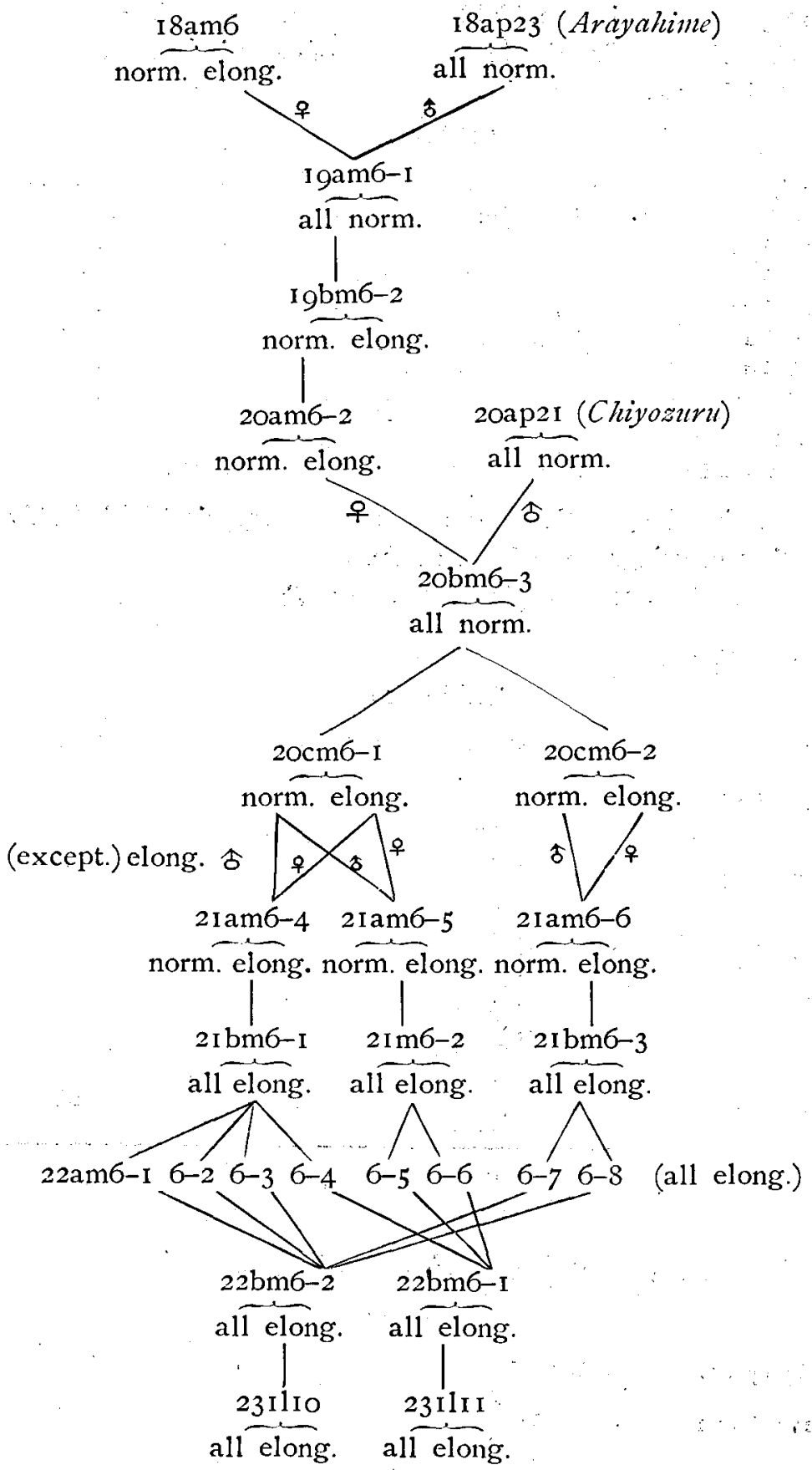




\section{E. Exceptional Individuals}

As may be seen in the Tables, there were sometimes met with exceptional males and females in the course of experiments. Such cases are collected below.

Table I2

\begin{tabular}{|c|c|c|c|}
\hline Family No. & Nature of the Family & Females (normal) & Males (elongate) \\
\hline 22am6-1o & $F_{1}$ from elong. 오 $\times$ norm. 숭 & - & IO* \\
\hline 22am6-1I & $"$ & - & $\mathbf{I}$ \\
\hline $22 \mathrm{~cm} 6-3$ & , & - & 2 \\
\hline $22 \mathrm{~cm} 6-23$ & $"$ & - & $\mathbf{I}$ \\
\hline $20 \mathrm{~cm} 6-1$ & $\mathrm{~F}_{2}$ from elong. 우 $\times$ norm. 숭 & - & $2^{*}$ \\
\hline $22 a m 6-13$ & $\mathrm{~F}_{1}$ from norm. 우 $\times$ elong. 호 & 2 & - \\
\hline $22 \operatorname{ch} 12-3$ & " & $\mathbf{I}$ & - \\
\hline Totals & & 3 & 16 \\
\hline
\end{tabular}

* These individuals were used in the following experiments.

To examine the genetic character of the "exceptional " individuals, the following crossings have been made.

Pure normal 우 $\times$ exceptional elongate 송.

a) $\mathrm{F}_{1}$

\section{Table 13}

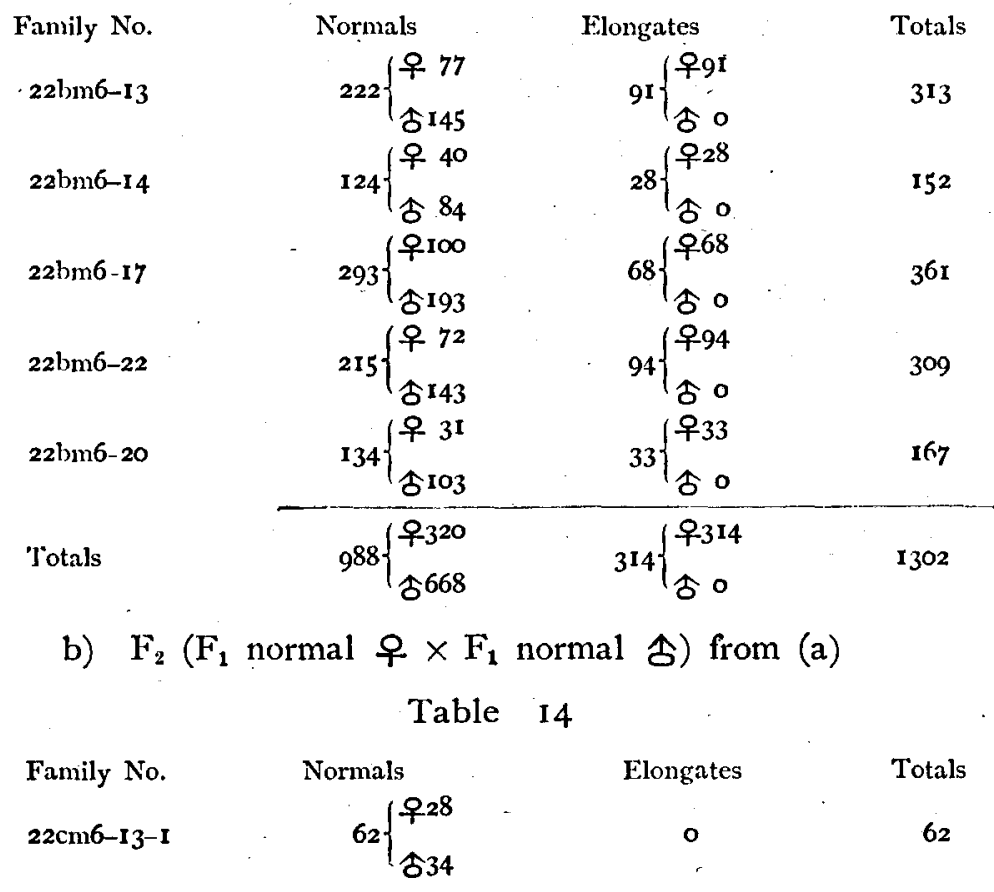




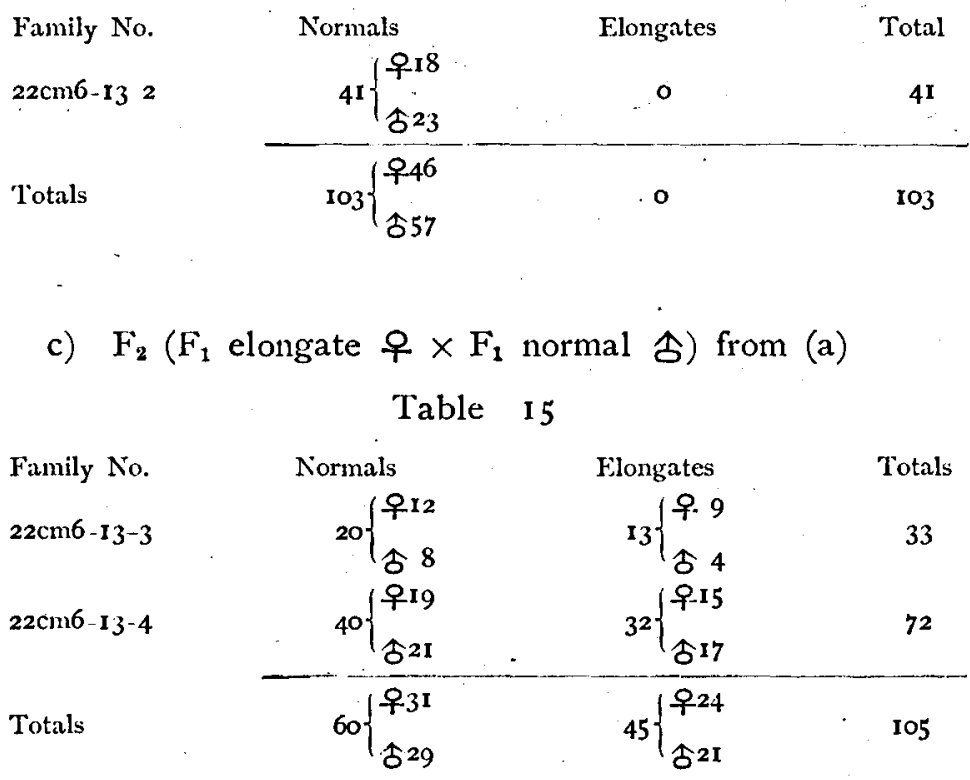

d) Back-crossing ( $F_{1}$ elongate 우 $\times$ pure normal 1 )

Table 16

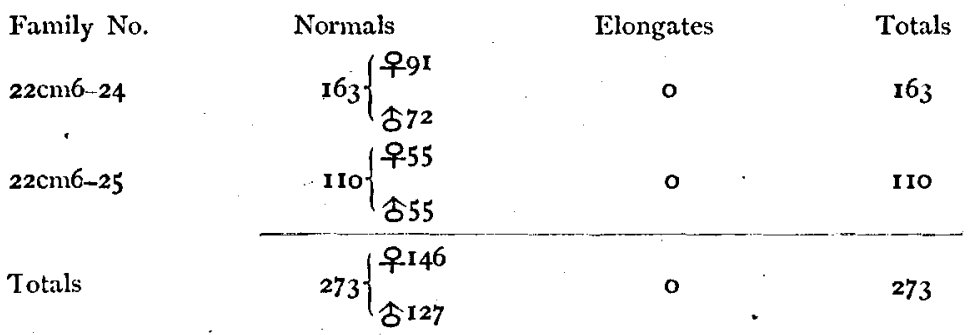

Pure elongate 우 $\times$ exceptional elongate 송

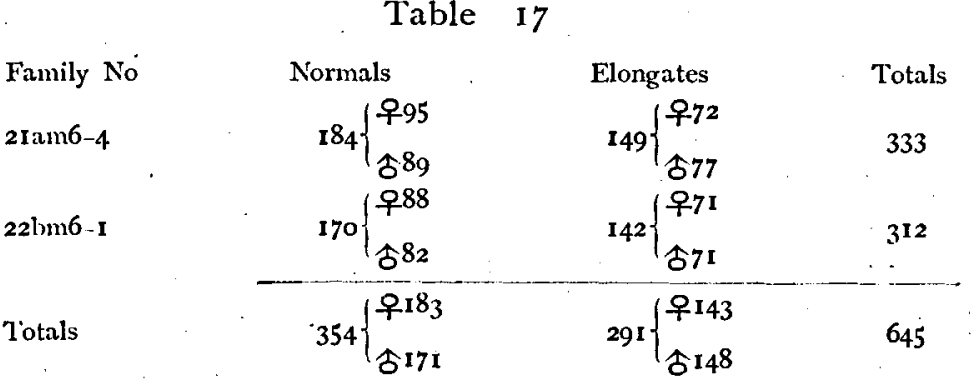




\section{CONCLUSION}

If the elongate is sex-linked in a similar way to the translucent of an Italian yellow race, the scheme of inheritance ought to be as follows :

(A)

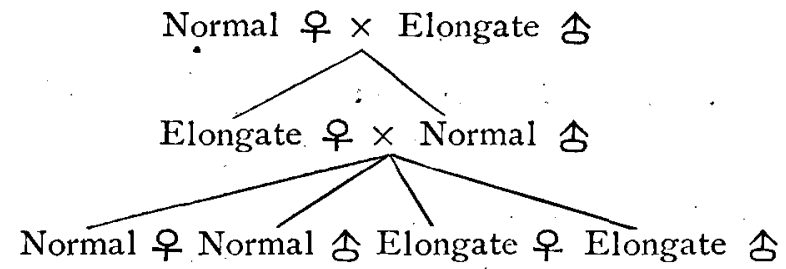

I : I : I : : I

(B)

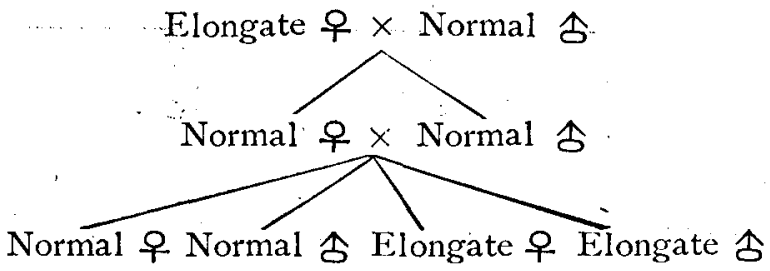

I : 2 : $\quad$ I.: : 0

(C)

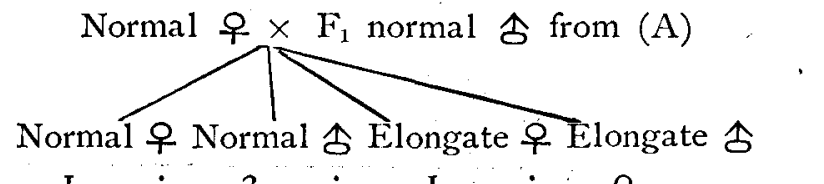

(D)

$\mathrm{F}_{\perp}$ Elongate 우 from $(\mathrm{A}) \times$ Normal 송 Elongate 우 $\times$ Elongate 송

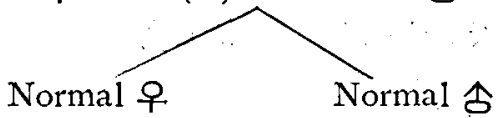

I

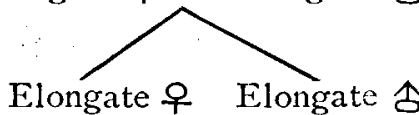

I

As is shown in Tables $3-10$, actual numbers are not very far from the theoretical ones calculated upon the above scheme; the deviations do not exceed three times the standard errors, with the exception only of $F_{2}$ families from the crossing normal 우 $\times$ elongate $\hat{\delta}$, in which the deficiency of the elongate is somewhat striking. This fact may, perhaps, be explained by differential vitality of the normal and the elongate. 
is seen in the Tables referred to, that the actual numbers of the elongate come always behind the expectation, especially where the mortality is high ${ }^{1)}$. An interesting case in this connection has been obtained after the Tables for this paper had been completed, and thus was not included in them. An $\mathrm{F}_{2}$ family, 22dm6-4-3, from the cross elongate 우 $\times$ normal 今, was reared during the period from October to December of 1922 . This unseasonable culture was accomplished with considerable difficulty, especially on account of bad conditions of food. 308 larvae hatched on I 3 th of October, and they were observed and counted for the first time on $4^{\text {th }}$ of December.

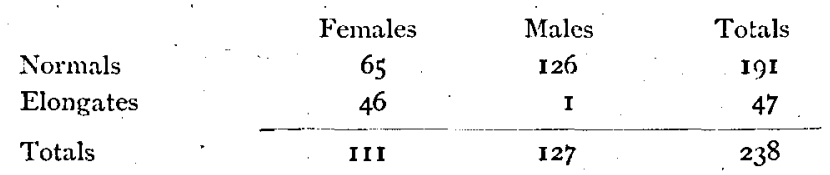

$U_{p}$ to that date, 77.3 per cent. still survived. It was about this time that the mulberry leaves begun to be frosted, and to turn yellow, hard and fibrous. After that the mortality increased rapidly, survival percentage dropping to 43.5 per cent. after only four days, or on 8 th of the same month, as shown below:

$\begin{array}{lccc} & \text { Females } & \text { Males } & \text { Totals } \\ \text { Normals } & 43 & 7 \mathbf{1} & \text { I } 44 \\ \text { Elongates } & \text { r } & \text { I } & 20 \\ \text { Totals } & 62 & 72 & \mathbf{1 3 4}\end{array}$

From this result, it is evident that the elongates suffer under the influence of unfavourable conditions more heavily than the normals; in the first count, the elongates occupied 19.7 per cent. of the entire family, while in the second the percentage came down to 14.9 .

The only exception to the above statement is the case given in Table 6. There were 37 I elongates to 302 normals while the expectation was equality in the numbers of the two types. Considering the rather high survival percentage in the families concerned, 84.6 , the case might be regarded as accidental.

Now we come to the consideration of the "exceptional" individuals. From Tables 12-17, we learn that the "exceptional" males behave quite similarly to the heterozy gous normals in inheritance, and they proved themselves not "exceptional" in a genetical sense. While externally they resemble the true elongate, and are easily distinguishable from

I) The initial number of the individuals in each family is not given in the Tables, but it is recorded in my protocols, from which we can calculate the mortality for each family. 
the normal, a minute examination will enable us to make out some difference between the true elongate and the "exception": it is a general rule in the latter that the elongation of the segments is somewhat slighter and the body harder than in the true elongate type. Though no experiment has as yet been made with the exceptional normal fimalis, it seems to me highly probable that they are also due to mere phenotypic aberration.

Admitting certain deviations due to the differential vitality, and counting the "exceptional" elongate males among the normals, and the "exceptional" normal females among the elongates, we come to the conclusion that the theoretical expectation is fairly realised, and the statement that Bombyx mori belongs to $\mathbf{Z Z ~ Z W}$ type in its chromosomal constitution is once more proved from the experimental side.

If we denote the elongate gene by $\theta$ and its normal allelomorph by $\mathbf{E}$, both the genes $\boldsymbol{e}$ and $\mathbf{o}^{\text {s }}$ (sex-linked translucent), their normal allelomorphs $\mathbf{E}$ and $\mathbf{O}^{3}$ also, are located in the sex-chromsome, $\mathbf{Z}$, consequently a certain form of linkage must take place in a dihybrid for the said two genes. This point will be made out on a future occasion.

The elongate silkworm has, so far as I am aware, never been reported elsewhere, and $I$ am confident that its origin is due to a mutation which occurred in one of my cultures. The family $18 \mathrm{am} 6$ in which the elongate made its first appearance was, most probably, derived from the cross $\mathbf{E}_{\boldsymbol{\theta}}$ 우 $\times \mathbf{E} \boldsymbol{\theta}$ 송, because it gave apparently normal males, normal females and elongate females in $2: I: I$ ratio. As the genetic constitution of the normal female is always $\mathbf{E e}$, the mutation can easily be supposed to have been introduced by the male parent which was taken from a pure breed of Chinese multilunar. Notwithstanding the recessive nature of the elongate, it could not, in virtue of its linkage with sex, pass many generations without being detected. The mutation must have occurred in the spring of 1917 or of 1916 , but not earlier.

On the other hand, I have occasionally met with in various strains having no apparent blood-relation with those described in the foregoing pages occurrence of caterpillars externally similar to the elongate. The elongate character in them was seldom markedly developed, and they were usually small in number (one or two for example, when they appeared), but also, though rarely, in considerable numbers. Though whether they are genetically identical with the elongate has not yet been ascertained, I am not unable to make a provisional suggestion in this direction. The elongate-like larvae occurred in a pure breed of Japanese bivoltine Aojiku gave, when mated among themselves, not only the elongates but 
also the normals. Even after a continued selection for four generations, the character did not fix, segregating both types in each generation. The percentage of abnormals did also not increase at all, it remained always under 25 per cent. It can be imagined, therefore, that they were quite different from the elongate in a genetical sense, if they have any, or were mere somatic aberrants.

I wish to express my thanks to Dr. T. KaGayama, Director of Imperial Sericultural Experiment Station, for his kindness in permitting me to make part of the present experiments in Fukushima Branch Station for several years. My obligation is also due to Mr. S. Matsuno, my assistant, who continued the experiments in a satisfactory manner during my two years' travelling abroad.

\section{SUMMARY}

I. A second case of the sex-linkage in the silkworm is reported in the present paper.

2. The character concerned is called "elongate."

3. The elongate is a new character first observed in the spring of 1918. by $\mathbf{E}$

4. We denote the elongate gene by $e$ and its normal allelomorph 


\section{LITERATURE CITED.}

Bridges, C. B. 1916. Non-disjunction as proof of the chromosome theory of heredity. Genetics, Vol. I.

Tanaka, X. 1917. Sex-linked inheritance in the silkworm, a preliminary. Report of Jap. Seric. Assoc. (In Japanese.)

Tanaka, Y. 1922. Sex-linked inheritance in the silkworm. Journ. Genetics, Vol. 12, No. 2

\section{EXPLANATION OF PLATE I}

Fig. I. The larvae, full grown, natural size.

From left to right :

. I. Elongate, dorsal.

2. Normal, dorsal.

3. Elongate, Jateral.

4. Normal, lateral.

Fig. 2. The pupae, magnified.

Left. Normal.

Right. Flongate.

Fig. 3. The pupae, natural size.

Upper row. Normals.

From left to right:

1-3. Dorsal.

4. Ventral.

5. Lateral.

Lower row. Elongates.

From left to right:

I-3. Dorsal, in the order of the degree of development of the characteristic.

4. Ventral.

5. Lateral.

La preskorektado de ĉi tiu verko de D-ro Tanaka preskaŭ finiĝ̀is je la I-a de Septembro, I923, kiam okazis en Tokio la tertremego, kiun sekvis brulego. Nia presejo ankaŭ farighis viktimo de la ruinigho. Estas tre bedaŭrinde, ke la publikigo de la verko tiel prokrastis pro tia kaŭzo. Ni tie ći esprimas nian tutkoran apologion al D-ro Tanaka. Ankaŭ ni dankas al la presisto, kiu malgraŭ sia malfacila situacio penadis ripeti la laboron por ni tiel rapide.-Redakcio.

$$
\text { (La I8-an de Marto, I924.) }
$$


Jour. Dept. Agric., Kyushu Imp. Univ. Vol. 1, No. 2.

Plate 1
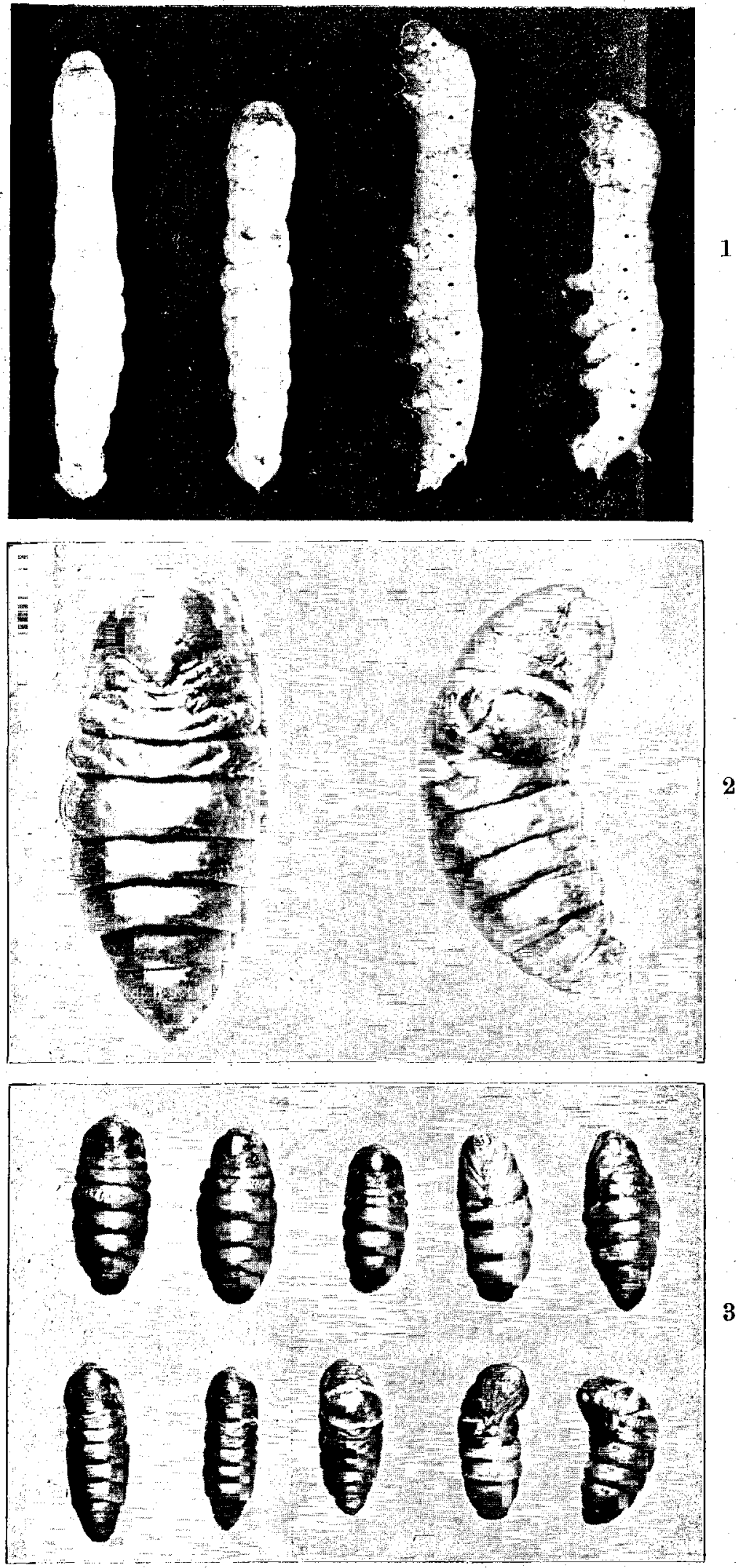